\title{
Front Matter: Volume 8936
}

, "Front Matter: Volume 8936," Proc. SPIE 8936, Design and Quality for Biomedical Technologies VII, 893601 (11 March 2014); doi: $10.1117 / 12.2053708$

SPIE. Event: SPIE BiOS, 2014, San Francisco, California, United States 


\title{
PROGRESS IN BIOMEDICAL OPTICS AND IMAGING
}

\section{Design and Quality for Biomedical Technologies VII}

\author{
Ramesh Raghavachari \\ Rongguang Liang \\ Editors
}

1-2 February 2014

San Francisco, California, United States

Sponsored and Published by

SPIE 
The papers included in this volume were part of the technical conference cited on the cover and title page. Papers were selected and subject to review by the editors and conference program committee. Some conference presentations may not be available for publication. The papers published in these proceedings reflect the work and thoughts of the authors and are published herein as submitted. The publisher is not responsible for the validity of the information or for any outcomes resulting from reliance thereon.

Please use the following format to cite material from this book:

Author(s), "Title of Paper," in Design and Quality for Biomedical Technologies VII, edited by Ramesh Raghavachari, Rongguang Liang, Proceedings of SPIE Vol. 8936 (SPIE, Bellingham, WA, 2014) Article CID Number.

ISSN: 1605-7422

ISBN: 9780819498496

Published by

SPIE

P.O. Box 10, Bellingham, Washington 98227-0010 USA

Telephone +1 3606763290 (Pacific Time) · Fax +1 3606471445

SPIE.org

Copyright @ 2014, Society of Photo-Optical Instrumentation Engineers.

Copying of material in this book for internal or personal use, or for the internal or personal use of specific clients, beyond the fair use provisions granted by the U.S. Copyright Law is authorized by SPIE subject to payment of copying fees. The Transactional Reporting Service base fee for this volume is $\$ 18.00$ per article (or portion thereof), which should be paid directly to the Copyright Clearance Center (CCC), 222 Rosewood Drive, Danvers, MA 01923. Payment may also be made electronically through CCC Online at copyright.com. Other copying for republication, resale, advertising or promotion, or any form of systematic or multiple reproduction of any material in this book is prohibited except with permission in writing from the publisher. The CCC fee code is $1605-7422 / 14 / \$ 18.00$.

Printed in the United States of America.

Publication of record for individual papers is online in the SPIE Digital Library.

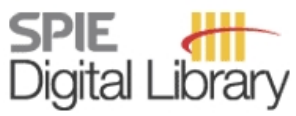

SPIEDigitalLibrary.org

Paper Numbering: Proceedings of SPIE follow an e-First publication model, with papers published first online and then in print and on CD-ROM. Papers are published as they are submitted and meet publication criteria. A unique, consistent, permanent citation identifier (CID) number is assigned to each article at the time of the first publication. Utilization of CIDs allows articles to be fully citable as soon as they are published online, and connects the same identifier to all online, print, and electronic versions of the publication. SPIE uses a six-digit CID article numbering system in which:

- The first four digits correspond to the SPIE volume number.

- The last two digits indicate publication order within the volume using a Base 36 numbering

system employing both numerals and letters. These two-number sets start with 00, 01, 02, 03, 04, $05,06,07,08,09,0 A, 0 B \ldots$. 0Z, followed by 10-1Z, 20-2Z, etc.

The CID Number appears on each page of the manuscript. The complete citation is used on the first page, and an abbreviated version on subsequent pages. Numbers in the index correspond to the last two digits of the six-digit CID Number. 


\section{Contents}

vii Conference Committee

SIMULATION AND APPLICATIONS OF BIOMEDICAL IMAGING TECHNOLOGIES

893602 Simulation of light transport in arthritic-and non-arthritic human fingers [8936-1]

M. Milanic, L. A. Paluchowski, L. L. Randeberg, Norwegian Univ. of Science and Technology (Norway)

893603 Optical-thermal light-tissue interactions during photoacoustic imaging [8936-2]

T. Gould, Q. Wang, T. J. Pfefer, U.S. Food and Drug Administration (United States)

893604 Spectrum correction considering light source fluctuation for non-invasive blood glucose sensing [8936-3]

S. Suzuki, A. Ishida, P. K. W. Abeygunawardhana, K. Wada, A. Nishiyama, I. Ishimaru,

Kagawa Univ. (Japan)

893606 Electrochemical impedance spectroscopy based-on interferon-gamma detection [8936-5]

G. Li, Y. Kuo, P. Tsai, C. Lee, National Taiwan Univ. (Taiwan)

\section{OCT SYSTEMS}

893608 Telemedicine + OCT: toward design of optimized algorithms for high-quality compressed images [8936-7]

M. Mousavi, Univ. of California, San Diego (United States); K. Lurie, Stanford Univ. (United States); J. Land, T. Javidi, Univ. of California, San Diego (United States); A. K. Ellerbee, Stanford Univ. (United States)

893609 Objective assessment of multimodality optical coherence tomography and secondharmonic generation image quality of ex vivo mouse ovaries using human observers [8936-8]

W. A. Welge, College of Optical Sciences, The Univ. of Arizona (United States);

A. T. DeMarco, J. M. Watson, P. S. Rice, The Univ. of Arizona (United States); J. K. Barton, College of Optical Sciences, The Univ. of Arizona (United States) and The Univ. of Arizona (United States); M. A. Kupinski, College of Optical Sciences, The Univ. of Arizona (United States)

8936 OA Simultaneous measurement of lipid and aqueous layers of tear film using optical coherence tomography and statistical decision theory [8936-9]

J. Huang, Univ. of Rochester (United States); E. Clarkson, The Univ. of Arizona (United

States); M. Kupinski, College of Optical Sciences, The Univ. of Arizona (United States);

J. P. Rolland, The Institute of Optics, Univ. of Rochester (United States) 
8936 OD Novel measure for the calibration of laser Doppler flowmetry devices [8936-11] A. V. Dunaev, Univ. of Dundee (United Kingdom) and State Univ. Educational Scientific Production Complex (Russian Federation); E. A. Zherebtsov, State Univ. Educational Scientific Production Complex (Russian Federation); D. A. Rogatkin, Moscow Regional Research and Clinical Institute (Russian Federation); N. A. Stewart, S. G. Sokolovski, E. U. Rafailov, Univ. of Dundee (United Kingdom)

8936 OF Reproducibility analysis of measurements with a mechanical semiautomatic eye model for evaluation of intraocular lenses [8936-14] E. Rank, Fachhochschule Technikum Wien (Austria) and Austrian Ctr. for Medical Innovation and Technology (Austria); L. Traxler, N. Bayer, B. Reutterer, Fachhochschule Technikum Wien (Austria); K. Lux, Austrian Ctr. for Medical Innovation and Technology (Austria); A. Drauschke, Fachhochschule Technikum Wien (Austria)

8936 OG A novel yet effective motion artefact reduction method for continuous physiological monitoring [8936-15]

A. Alzahrani, S. Hu, V. Azorin-Peris, R. Kalawsky, X. Zhang, C. Liu, Loughborough Univ. (United Kingdom)

\section{BIOMEDICAL IMAGING TECHNOLOGIES I}

8936 OK Effect of modulation frequency bandwidth on measurement accuracy and precision for digital diffuse optical spectroscopy (dDOS) [8936-20]

J. Jung, Boston Univ. (United States) and Univ. of Waterloo (Canada); R. Istfan, D. Roblyer, Boston Univ. (United States)

\section{INTRAOPERATIVE SYSTEMS}

8936 OP Intraoperative imaging and fluorescence image guidance in oncologic surgery using a wearable fluorescence goggle system [8936-25]

S. B. Mondal, S. Gao, Washington Univ. in St. Louis (United States); N. Zhu, College of Optical Sciences, The Univ. of Arizona (United States); Y. Liu, G. P. Sudlow, W. J. Akers, Washington Univ. in St. Louis (United States); R. Liang, College of Optical Sciences, The Univ. of Arizona (United States); V. Gruev, S. Achilefu, Washington Univ. in St. Louis (United States)

8936 OR Scanning Fiber Endoscope with multiple fluorescence-reflectance imaging channels for guiding biopsy [8936-27]

C. Yang, V. W. Hou, L. Y. Nelson, R. S. Johnston, C. D. Melville, E. J. Seibel, Univ. of Washington (United States)

\section{BIOMEDICAL IMAGING TECHNOLOGIES II}

8936 OV System design and evaluation of the array confocal fluorescence microscope [8936-31] S. Pacheco, T. Milster, College of Optical Sciences, The Univ. of Arizona (United States); J. Zhou, DMetrix, Inc. (United States); R. Liang, College of Optical Sciences, The Univ. of Arizona (United States) 
$89360 Z$ Optical testing of progressive ophthalmic glasses based on galvo mirrors [8936-34] S. Stuerwald, R. Schmitt, Fraunhofer-Institut für Produktionstechnologie (Germany) and RWTH Aachen Univ. (Germany)

893612 Advancements on galvanometer scanners for high-end applications [8936-37] V.-F. Duma, Aurel Vlaicu Univ. of Arad (Romania); J. P. Rolland, Institute of Optics, Univ. of Rochester (United States)

\section{POSTERS SESSION}

893613 Effect of noise levels of an edge image on determining the presampled modulation transfer function [8936-38]

W. Wan, Tianjin Univ. (China); F. Gao, H. Zhao, L. Zhang, Z. Zhou, Tianjin Univ. (China) and Tianjin Key Lab. of Biomedical Detecting Techniques and Instruments (China)

893614 3D papillary image capturing by the stereo fundus camera system for clinical diagnosis on retina and optic nerve [8936-39]

D. A. Motta, A. Serillo, Wavetek Technologies Industry Ltd. (Brazil); L. de Matos, F. M. M. Yasuoka, Wavetek Technologies Industry Ltd. (Brazil) and Univ. de São Paulo (Brazil); V. S. Bagnato, Univ. de São Paulo (Brazil); L. A. V. Carvalho, Wavetek Technologies Industry Ltd. (Brazil) and Univ. de São Paulo (Brazil)

893615 Extracting optical properties of turbid media using radially and spectrally resolved diffuse reflectance [8936-40]

J. Malsan, Radiation Monitoring Devices, Inc. (United States) and Northeastern Univ. (United States); R. Gurjar, D. Wolf, K. Vishwanath, Radiation Monitoring Devices, Inc. (United States)

893616 Characterization and modeling of point spread function in push-broom hyperspectral imaging systems for spectral and spatial resolution enhancement [8936-41]

J. Jemec, M. Bürmen, Univ. of Ljubljana (Slovenia); M. Kosec, Sensum Computer Vision Systems (Slovenia); F. Pernuš, B. Likar, Univ. of Ljubljana (Slovenia) and Sensum Computer Vision Systems (Slovenia)

Author Index 
Proc. of SPIE Vol. $8936893601-6$

Downloaded From: https://www.spiedigitallibrary.org/conference-proceedings-of-spie on 26 Apr 2023 Terms of Use: https://www.spiedigitallibrary.org/terms-of-use 


\title{
Conference Committee
}

\author{
Symposium Chairs
}

James G. Fujimoto, Massachusetts Institute of Technology

(United States)

R. Rox Anderson, Wellman Center for Photomedicine, Massachusetts General Hospital (United States) and Harvard School of Medicine (United States)

Program Track Chairs

Tuan Vo-Dinh, Fitzpatrick Institute for Photonics, Duke University (United States)

Anita Mahadevan-Jansen, Vanderbilt University (United States)

Conference Chairs

Ramesh Raghavachari, U.S. Food and Drug Administration (United States)

Rongguang Liang, College of Optical Sciences, The University of Arizona (United States)

Conference Co-chair

T. Joshua Pfefer, U.S. Food and Drug Administration (United States)

Conference Program Committee

Anthony J. Durkin, Beckman Laser Institute and Medical Clinic (United States)

Kenji Taira, Olympus Corporation (United States)

Jeeseong Hwang, National Institute of Standards and Technology (United States)

Stephen P. Morgan, The University of Nottingham (United Kingdom)

Robert J. Nordstrom, National Institutes of Health (United States)

Jannick P. Rolland, University of Rochester (United States)

Eric J. Seibel, University of Washington (United States)

Tomasz S. Tkaczyk, Rice University (United States)

Rudolf $\mathbf{M}$. Verdaasdonk, Vrije University Medical Center (Netherlands)

David W. Allen, National Institute of Standards and Technology

(United States) 


\section{Session Chairs}

1 Simulation and Applications of Biomedical Imaging Technologies

Rudolf $\mathbf{M}$. Verdaasdonk, Vrije University Medical Center (Netherlands)

2 OCT Systems

T. Joshua Pfefer, U.S. Food and Drug Administration (United States)

3 Quality of Biomedical Imaging Technologies

T. Joshua Pfefer, U.S. Food and Drug Administration (United States)

4 Biomedical Imaging Technologies I

Anthony J. Durkin, Beckman Laser Institute and Medical Clinic (United States)

5 Standards and Phantoms in Biophotonics: Joint Session with Conferences 8936 and 8945

Robert J. Nordstrom, National Institutes of Health (United States)

Ramesh Raghavachari, U.S. Food and Drug Administration (United States)

6 Intraoperative Systems

Rongguang Liang, College of Optical Sciences, The University of Arizona (United States)

$7 \quad$ Biomedical Imaging Technologies II

Ramesh Raghavachari, U.S. Food and Drug Administration

(United States)

8 Optics for Biomedical Imaging Technologies

Jeeseong Hwang, National Institute of Standards and Technology (United States) 